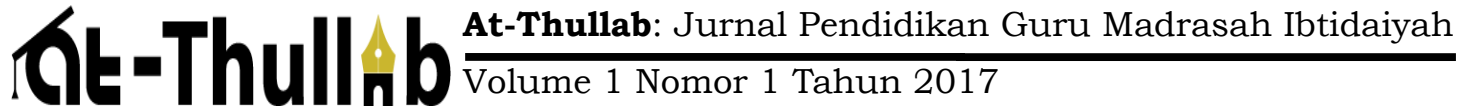

\section{PENGGUNAAN MEDIA GRAFIS (PETA KONSEP) DALAM PEMBELAJARAN SEJARAH UNTUK MEMPERMUDAH PEMAHAMAN SISWA KELAS V MI DARUL ULUM BOJONEGORO}

\author{
Yulia Pramusinta \\ Program Studi Pendidikan Guru Madrasah Ibtidaiyah \\ Universitas Islam Lamongan \\ e-mail : yusintaalwahab@gmail.com
}

\begin{abstract}
The teaching medium is a knowledge of the teaching methods used by a teacher or instructor. Methods are the means used to achieve the established goals. Another technique is the presentation technique that is mastered by the teacher to teach or present the lesson materials to the students in the classroom, so that the lesson can be absorbed, understood and used by the students well. The better the teaching method, the more effective the achievement of the goal. Motivation is a change of energy within a person characterized by the emergence of "feeling and preceded by the response to the purpose, to get it then must be selected methods that if acceptable in teaching and learning activities well. In fact, the way or method of teaching used to convey different information in the way adopted to establish students in mastering knowledge, skills and attitudes (cognitive, psychomotoric, affective). Specific methods of teaching in the classroom, the effectiveness of a method is influenced by the purpose, student factors, situation factors, and teacher factor itself. Demonstration is a teaching method done by a teacher or someone else by showing the whole class about a process or a way of doing something. Demonstrations are always directed to the correct way of practice which is then Apliskasikan in everyday life. And recitation is also one of the learning media known as homework or students are given the task outside of lesson time. Both methods can be implemented simultaneously in the teaching and learning process. From the above statements can be concluded that in learning, students so as not to get bored then there should be variations in learning methods. Teachers must be clever in choosing a method, one of which is the Graphic method (concept map). In this case on the history of the use of Graphic method (concept map) is the right method to invite students to think and understand and apply in everyday life. Graphical Pendekata (konse map) invites us to make learning process more meaningful and conductive.
\end{abstract}

Kewords: Grafis Media, Learning History, Student Chomprehensif 


\section{A. Pendahuluan}

Pembelajaran merupakan suatu proses yang dilakukan secara sadar pada setiap individu atau kelompok untuk merubah sikap dari tidak tahu menjadi tahu sepanjang hidupnya. Sedangkan proses belajar mengajar adalah suatu kegiatan yang di dalamnya terjadi proses siswa belajar dan guru mengajar dalam konteks interaktif, dan terjadi interaksi edukatif antara guru dan siswa, sehingga terdapat perubahan dalam diri siswa baik perubahan pada tingkat pengetahuan, pemahaman dan ketrampilan atau sikap (Hamalik, 2001).

Sedangkan pembelajaran sejarah adalah suatu upaya membelajarkan peserta didik agar dapat belajar, terdorong belajar, mau belajar dan tertarik untuk terus menerus mempelajari sejarah, baik untuk kepentingan diri sendiri maupun mempelajari untuk memperluas ilmu pengetahuan (Muhaimin, 2002)

Oleh karena itu, proses belajar mengajar yang di selenggarakan di sekolah atau lembaga formal, dimaksudkan untuk mengarahkan perubahan diri siswa secara terencana, baik perubahan dalam pengetahuan, pemahaman dan ketrampilan atau sikap. Proses belajar mengajar di sekolah atau di lembaga formal sangat dipengaruhi oleh lingkungan belajar. Lingkungan belajar tersebut antara lain meliputi: siswa, guru, karyawan sekolah, bahan atau meteri pelajaran (buku paket, majalah, makalah dsb), sumber belajar lain yang mendukung dan fasilitas belajar (laboratorium, pusat sumber belajar, perpustakaan yang lengkap dan sebagainya).

Guru adalah orang yang penting statusnya di dalam kegiatan belajar mengajar, karena guru memegang tugas yang paling penting yaitu mengatur dan mengemudikan bahtera kehidupan kelas. Bagaimana suasana kelas berlangsung merupakan hasil kerja dari guru. Suasana dapat "hidup" siswa belajar tekun tapi tidak merasa terkekang atau sebagainya, suasana "muram" siswa belajar kurang bersemangat dan diliputi suasana takut. Itu semuanya sebagai akibat dari hasil pemikiran dan upaya guru (Saputro, 1993).

Bersamaan dengan perkembangan zaman, kemajuan ilmu pengetahuan dan teknologi semakin maju dan juga mendorong guru untuk mengadakan upaya pembaharuan dalam proses belajar dan memanfaatkan hasil-hasil teknologi. Guru di tuntut untuk mampu menggunakan alat-alat yang bisa memudahkannya dalam menjalankan proses belajar mengajar dan memudahkan siswa dalam belajar, baik alat bantu yang sesuai dengan perkembangan zaman seperti komputer, slide dan sebagainya. Ataupun alat bantu mengajar yang sederhana, murah dan efisien seperti gambar, grafik, dan bagan. Untuk mencapai tujuan pembelajaran di samping guru di tuntut mampu menggunakan alat-alat tersebut, guru juga di tuntut untuk mampu mengembangkan media pembelajaran yang akan digunakan tetapi tersedia, karena media adalah bagian yang tidak terpisahkan dari proses belajar mengajar demi tercapainya tujuan pembelajaran (Arief S, n.d.) 
Media pembelajaran yang dapat digunakan dalam proses belajar mengajar banyak sekali, begitu juga dalam pembelajaran sejarah juga bisa menggunakan media pembelajaran untuk memudahkan guru, siswa dalam belajar. Media yang dimanfaatkan dalam pembelajaran sejarah, antara lain: komputer, rekaman $\mathrm{CD}$, gambar, grafis (peta konsep) dan sebagainya. Media-media tersebut mempunyai karakteristik tersendiri, sehingga dapat memudahkan dalam mempelajari mata pelajaran sejarah yang ada di sekolah-sekolah terutama di lembaga formal.Berdasarkan diskripsi di atas dan agar lebih terfokus dalam pembahasan penelitian ini, maka peneliti memusatkan perhatian pada pertanyaan sebagai berikut:Apakah penggunaan media grafis dalam mempelajari sejarah dapat mempermudah siswa-siswi kelas 5 MI Darul Ulum Bojonegoro? Bagaimanakah penggunaan media grafis dalam pembelajaran sejarah kelas 5 MI Darul Ulum Bojonegoro?

\section{Pengertian Pembelajaran Sejarah}

Pendidikan Sejarah adalah upaya sadar dan terencana dalam menyiapkan peserta didik untuk mengenal, memahami, menghayati ilmu Sejarah tersebut.

Zakiyah Darajat (Darajat, 1987) mengemukakan bahwa esensi pendidikan yaitu adanya proses transfer nilai, pengetahuan dan keterampilan dari generasi tua ke generasi muda agar generasi muda mampu untuk hidup. Oleh karena itu ketika kita menyebut Sejarah, maka akan mencakup dua hal, yaitu:

1. Mendidik siswa-siswi untuk mengenal, memahami serta mendalami tentang sejarahsejarah tersebut.

2. Mendidik siswa-siswi untuk mempelajari materi sejarah, berupa pengetahuan tentang sejarah-sejarah zaman dahulu.

Jadi pendidikan Sejarah merupakan usaha sadar yang dilakukan pendidik dalam rangka mempersiapkan peserta didik untuk mendalami, memahami dan memperluas ilmu agar tercapai tujuan yang diinginkan dan ditetapkan.

Dari pengertian tersebut dapat ditemukan beberapa hal yang perlu diperhatikan dalam pembelajaran sejarah, yaitu sebagai berikut:

Pendidikan sejarah sebagai usaha sadar, yakni suatu kegiatan bimbingan, pengajaran dan latihan yang dilakukan secara berencana dan sadar atas tujuan yang hendak dicapai.

1. Peserta didik yang hendak disiapkan untuk mencapai tujuan, dalam arti ada yang dibimbing, diajari dan dilatih dalam peningkatan ilmu pengetahuan dan mempersiapkan generasi penerus bangsa yang berkualitas.

2. Pendidik sejarah yang melakukan kegiatan bimbingan, pengajaran dan latihan secara sadar terhadap peserta didiknya untuk mencapai tujuan yang di inginkan. 
Pembelajaran sejarah diarahkan untuk meningkatkan rasa nasionalisme dan cinta tanah air sehingga tercapai kemakmuran.

\section{Tujuan dan Ruang Lingkup Pembelajaran sejarah.}

Secara umum, Pendidikan sejarah bertujuan untuk meningkatkan keimanan, pemahaman, penghayatan, dan pengamalan peserta didik tentang agama Islam, sehingga menjadi manusia muslim yang beriman dan bertaqwa kepada Allah SWT. serta berakhlak mulia dalam kehidupan pribadi, bermasyarakat, berbangsa dan bernegara (Muhaimin, 2001).

Dari tujuan tersebut dapat ditarik beberapa dimensi yang hendak ditingkatkan dan dituju oleh pembelajaran agama Islam, yaitu: dimensi keimanan peserta didik terhadap ajaran agama Islam, dimensi pemahaman atau penalaran serta keilmuan peserta didik terhadap ajaran agama Islam; dimensi penghayatan dan pengamalan batin yang dirasakan peserta didik dalam menjalankan ajaran Islam, dimensi pengalaman, dalam arti bagaimana ajaran Islam yang telah di Imani, dipahami, dan dihayati oleh peserta didik itu mampu diamalkan dalam kehidupan pribadi, sebagai manusia yang beriman dan bertaqwa kepada Allah SWT. dan berakhlak mulia, serta diaktualisasikan dalam kehidipan bermasyarakat, berbangsa dan bernegara (Muhaimin, 2001) 
Pendidikan Agama Islam dijenjang pendidikan dasar bertujuan memberikan kemampuan dasar kepada peserta didik tentang agama Islam untuk mengembangkan kehidupan beragama, sehingga menjadi manusia muslim yang beriman dan bertaqwa kepada Allah SWT serta berakhlak mulia sebagai pribadi, anggota masyarakat, warga negara dan anggota umat manusia. Sedangkan Pendidika Agama Islam pada jenjang menengah bertujuan untuk meningkatkan keyakinan, pemahaman, penghayatan, dan pengalaman peserta didik tentang agama Islam, sehingga menjadi manusia yang beriman dan bertaqwa kepada Allah SWT dan berakhlak mulia, serta diaktualisasikan dalam kehidupan bermasyarakat, berbangsa dan bernegara, serta untuk melanjutkan kejenjang yang lebih tinggi.

Untuk mencapai tujuan tersebut, maka ruang lingkup pendidikan agama Islam meliputi keserasian, keselarasan dan keseimbangan antara:

1. Hubungan manusia dengan Allah,

2. Hubungan manusia dengan sesama makhluk,

3. Hubungan manusia dengan dirinya sendiri,

4. Dan hubungan manusia dengan makhluk lain dan lingkungannya.

Dari ruang lingkup tersebut, kemudian dijabarkan dalam kurikulum PAI 1994., yang pada dasarnya mencakup tujuh unsur pokok yaitu: Al-Qur'an, hadits, keimanan, syari'ah, ibadah, muamalah, akhlak, dan tarikh yang menekankan pada perkembangan poltik. Pada kurikulum 1999 dipadatkan menjadi lima unsur pokok yaitu: al-Qur'an, keimanan, akhlak, fiqih, dan bimbingan ibadah, serta tarikh atau sejarah yang lebih menekankan pada perkembengan ajaran agama, ilmu pengetahuan dan kebudayaan.

\section{Pengertian Media Pengajaran}

Kata media merupakan bentuk jamak dari medium yang berarti perantara, sedangkan menurut istilah adalah wahana pengantar pesan. Beberapa teknologi pengajaran, banyak memberikan batasan definisi tentang media pengajaran, diantaranya:

1. Menurut AECT (Association of Education end Communication Tecnonology) memberi batasan mengenai media sebagai segala bentuk dan saluran yang digunakan orang untuk menyalurkan pesan atau informasi.

2. Menurut NEA (National Education Assocation) menyatakan bahwa media adalah bentuk-bentuk komunikasi baik tercetak maupun audio visual serta peralatannya. Dan hendakanya dapat dimanipulasi, dilihat, didengar dan dibaca.

3. Gagne menyatakan bahwa, media adalah berbagai jenis komponen dalam lingkungan siswa yang dapat merangsangnya untuk belajar. 
4. Briggs berpendapat, media adalah segala alat fisik yang dapat menyajikan pesan serta merangsang siswa untuk belajar, misalnya buku, film bingkai, kaset dan lainlain (Soetomo, 1993).

Perkembangan selanjutnya Martin dan Briggs memberikan batasan mengenai media pembelajaran yaitu mencakup semua sumber yang diperlukan untuk melakukan komunikasi dengan siswa (Muhaimin, 2001). Kesimpulan dari berbagai pendapat di atas adalah:

1. Media adalah wadah dari pesan yang oleh sumber atau penyalurnya ingin diteruskan kepada penerima pesan tersebut.

2. Bahwa materi yang ingin disampaikan adalah pesan instruksional.

3. Tujuan yang ingin dicapai adalah terjadinya proses belajar pada penerima pesan (anak didik).

Berdasarkan beberapa batasan tentang media pengajaran, maka dapat dikemukakan ciri-ciri umum yang terkandung dalam media pengajaran, antara lain :

1. Media pembelajaran memiliki pengertian fisik yang dewasa ini dikenal sebagai hardware (perangkat keras), yaitu sesuatu yang dapat dilihat, didengar atau diraba dengan panca indera.

2. Media pembelajaran memiliki pengertian non fisik yang dikenal sebagai soft ware (perangkat lunak), yaitu kandungan pesan yang terdapat dalam perangkat keras yang meupakan isi yang ingin disamapaikan kepada siswa.

3. Penekanan media pembelajaran terdapat pada visual dan audio.

4. Media pembelajaran memiliki pengertian alat bantu pada proses belajar baik dalam kelas maupun di luar kelas.

5. Media pembelajaran digunakan dalam rangka komunikasi dan interaksi guru dan siswa dalam proses belajar mengajar.

6. Media pembelajaran dapat digunakan secara massa (misalnya: radio, televisi) kelompok besar dan kelompok kecil (misalnya: slide, film, vidio,OHP) atau perorangan (misalnya : modul, komputer, radio, tape/kaset video recorder).

7. Sikap, perbuatan, organisasi, strategi, dan manajemen yang berhubungan dengan suatu ilmu (Arsyad, 2002).

Jadi dari batasan-batasan dan ciri-ciri umum di atas media pengajaran berupa hard ware dan soft ware dan bisa dilihat serta didengar dan juga bisa membantu guru untuk memperlancar dalam proses belajar mengajar sehingga terjadi komunikasi dan interaksi edukatif. Dan membantu mempermudah siswa dalam memahami pesan yang disampaikan oleh guru. 


\section{Jenis-jenis Media Pengajaran}

Ada beberapa jenis media pengajaran yang dapat digunakan dalam proses belajar mengajar. Jenis media pengajaran tersebut, antara lain :

1. Media Grafis

Media grafis adalah media visual. Dalam media ini, pasan yang akan disampaikan dapat dituangkan dalam bentuk simbol. Oleh karena itu simbol-simbol yang digunakan perlu difahami benar artinya, agar dalam penyampaian materi dalam proses belajar mengajar dapat berhasil secara efektif dan efisien.

Media grafis berfungsi untuk menarik perhatian, memperjelas sajian ide, mengilustrasikan atau menghiasi fakta yang mungkin akan cepat dilupakan apabila tidak digrafiskan.

Media grafis selain sederhana dan mudah pembuatannya, media grafis juga termasuk media yang relatif murah ditinjau dari segi biayanya. Adapun jenis-jenis media grafis, antara lain:

2. Gambar/Foto

Media gambar adalah media yang paling umum dipakai.Gambar/Foto merupakan bahasa yang umum yang dapat dimengerti dan dinikmati di manamana.Sebagaimana pepatah cina mengatakan "sebuah gambar berbicara lebih banyak daripada seribu bahasa". Dalam penggunaan media pembelajaran ini, gambarnya harus disesuaikan dengan tujuan yang ingin dicapai.

a. Sketsa, Sketsa adalah gambar yang sederhana, atau draf kasar yang melukiskan bagian-bagian pokoknya tanpa detail. Karena setiap orang yang normal dapat diajar menggambar, maka setiap guru yang baik haruslah dapat menuangkan ideidenya dalam bentuk sketsa. Sketsa, selain dapat menarik perhatian siswa, menghindari verbalisme dan dapat memperjelas penyampaian pesan, harganya pun tak perlu dipersoalkan karena media dibuat guru langsung.

b. Diagram, Diagram adalah suatu gambar sederhana yang dirancang untuk menggambarkan hubungan timbal balik, yang menggunakan garis-garis dan simbol-simbol.Diagram biasanya menggambarkan struktur dari obyeknya secara garis besar, menunjukkan hubungan yang ada antar komponennya atau sifat-sifat proses yang ada di situ.

c. Bagan, Bagan seperti halnya media grafis yang lain yaitu termasuk media visual. Fungsinya yang pokok adalah menyajikan ide-ide atau konsep-konsep yang sulit bila hanya disampaikan secara tertulis atau lisan secara visual. Bagan juga mampu memberikan ringkasan butir-butir penting dari suatu presentasi. Pesan yang disampaikan biasanya berupa ringkasan visual suatu proses, perkembangan atau hubungan-hubungan penting. 
d. Grafik, Grafik adalah gambar sederhana yang menggunakan titik-titik, grafis atau gambar. Untuk melengkapinya seringkali simbol-simbol verbal digunakan pula di situ. Fungsinya adalah untuk menggambarkan data secara kuantitatif dan teliti, menerangkan perkembangan atau perbandingan sesuatu objek atau peristiwa yang saling berhubungan secara singkat dan jelas.

e. Kartun, Kartun sebagai salah satu bentuk komunikasi grafis, yaitu suatu gambar interpretatife yang digunakan simbol-simbol untuk menyampaikan sesuatu pesan secara cepat dan ringkas atau sesuatu sikap terhadap orang situasi, atau kejadiankejadian tertentu.Kemampuannya besar sekali untuk menarik perhatian, mempengaruhi sikap atau tingkah laku. Kartun biasanya hanya menangkap esensi pesan yang harus disampaikan dan menuangkannya ke dalam gambar sederhana, tanpa detail menggunakan simbol-simbol serta karakter yang mudah dikenal dan dipahami dengan cepat (Arief S, n.d.)

3. Media Audio

Media audio berbeda dengan media grafis, media audio berkaitan dengan indera pendengaran. Pesan yang akan disampaikan dituangkan kedalam lambanglambang auditif, baik verbal maupun non verbal. Ada beberapa jenis media yang dapat dikelompokkan dalam media audio, antara lain:

a. Radio, Radio adalah media audio yang programnya dapat direkam dan diputar sesuka kita.Media ini relatif murah dan variasi progamnya lebih banyak dan bisa dipindah-pindah dan dapat digunakan bersama-sama.

b. Alat Perekam Pita Magnetic (tape recorder), Alat perekam pita magnetic atau tape recorder adalah salah satu media pembelajaran yang tidak dapat diabaikan untuk menyampaikan informasi, karena mudah menggunakannya.

c. Laboratorium Bahasa, Laboratorium bahasa adalah alat untuk melatih siswa mendengar dan berbicara dalam bahasa asing dengan jalan menyajikan materi pelajaran yang disiapkan sebelumnya. Media ini yang dipakai adalah alat perkam (Arief S, n.d.).

\section{Media Proyeksi Diam}

Media proyaksi diam (still proyektif medium) mempunyai persamaan dengan media grafis dalam arti menyajikan rangsangan-rangsangan visual. Untuk itu bahanbahan grafis banyak sekali dipakai dalam media proyeksi diam. Perbedaan antara media grafis dan proyeksi diam, yaitu pada media grafis dapat secara langsung berinteraksi dengan pesan media bersangkutan, pada media proyeksi diam pesan yang terkandung di dalamnya harus diproyeksikan dengan proyektor agar dapat dilihat oleh sasaran (Arief S, n.d.). Dalam proyeksi diam ini semua menggunakan transparan yang kemudian diproyeksikan menggunakan proyektor. 


\section{Kriteria Pemilihan Media Pengajaran}

Dalam memilih media pembelajaran sebaiknya memperhatikan kriteria-kriteria sebagai berikut:

1. Ketepatannya dengan tujuan pembelajaran dipilih atas dasar tujuan-tujuan instruktional yang telah ditetepkan.

2. Dukungan terhadap isi bahan pelajaran, bahan pelajaran yang sifatnya fakta, prinsip, konsep dan generalisasi sangat memerlukan bantuan media agar lebih mudah difahami.

3. Kemudahan memperoleh media, media yang diperlukan mudah diperoleh, setidaknya mudah dibuat oleh guru pada waktu mengajar.

4. Keterampilan guru dalam menggunakannya, guru mampu menggunakannya, dengan baik dalam proses belajar mengajar.

5. Tersedia waktu untuk menggunakannya.

6. Sesuai dengan taraf berfikir siswa, memilih media pembelajaran sesuai dengan taraf berfikir siswa sehingga makna yang terkandung di dalamnya dapat difahami oleh siswa (Sudjana, 1989).

Dengan kriteria pemilihan media di atas, guru akan lebih mudah menggunakan media mana yang dianggap tepat untuk membantu dalam proses belajar mengajar sehingga dengan adanya media yang tepat dapat melaksanakan proses belajar mengajar dengan efektif dan efisien.

\section{Fungsi dan Manfaat Media Pengajaran}

Secara umum media pengajaran mempunyai fungsi sebagai berikut:

1. Memperjelas penyajian pesan agar tidak terlalu bersifat verbalitas, sehingga mempermudah siswa dalam memahami pesan tersebut.

2. Mengatasi keterbatasan ruang waktu dan daya indera.

3. Menarik perhatian siswa dalam proses belajar mengajar.

4. Menimbulkan gairah belajar pada siswa.

5. Memungkinkan terjadinya interaksi yang lebih langsung antara anak didik dengan lingkungan dan kenyataan.

6. Memungkinkan anak didik belajar sendiri-sendiri menurut kemampuan dan minatnya.

7. Mempersamakan pengalaman dan persepsi antar siswa dalam menerima pesan (Arief S, n.d.)

Berdasarkan batasan-batasan mengenai batasan media di atas, maka dapat disimpulkan bahwa media pengajaran segala sesuatu yang dapat digunakan untuk menyalurkan pesan pendidikan dari pengirim pesan atau guru kepada penerima pesan (siswa) dan dapat merangsang pikiran, perasaan, perhatian, dan minat serta perhatian 
siswa sehingga terjadi proses belajar mengajar yang mempermudah siswa dalam memahami pesan.

Menurut Oemar Hamalik, manfaat dari penggunaan media dalam proses belajar mengajar adalah:

1. Meletakkan dasar-dasar yang konkret dalam berfikir dan mengurangi verbalisme.

2. Memperbesar perhatian siswa dalam proses belajar mengajar

3. Meletakkan dasar-dasar yang penting untuk perkembangan proses belajar mengajar dan membuat pelajaran yang mantap.

4. Menumbuhkan pemikiran yang teratur, lentur dan kontinue terutama melalui gambar hidup membantu tumbuhnya pengertian yang dapat membantu perkembangan kemampuan berbahasa.

Memberikan pengalaman yang tidak mudah diperoleh dengan cara lain dan membantu efisiensi dan keragaman yang lebih banyak dalam belajar (Arsad, 1997).

\section{B. Metode}

1. Pendekatan dan Jenis Penelitian

Dalam penelitian ini peneliti memilih pendekatan kualitatif. Pendekatan kualitatif adalah pendekatan yang menghasilkan penemuan-penemuan yang tidak dapat diperoleh dengan menggunakan prosedur statistik atau dengan cara lain dari pengukuran (Anselm, 1997).

Sedangkan jenis penelitian yang digunakan adalah penelitian tindakan kelas yang bertujuan untuk memperbaiki atau meningkatkan kegiatan pembelajaran dalam mengatasi kesulitan siswa dalam pembelajaran.

Menurut T. Raka Joni dalam F.X Soedarsono penelitian tindakan kelas merupakan suatu bentuk kajian yang bersifat reflektif oleh pelaku tindakan yang dilakukan untuk meningkatkan kemampuan rasional dari tindakan-tindakan yang dilakukannya itu serta memperbaiki kondisi-kondisi dimana praktek-praktek pembelajaran tersebut dilakukan (Soedarsono, n.d.).

2. Tahapan Penelitian Tindakan Kelas

Penelitian ini dilakukan diSMA Negeri I Batu, dan difokuskan pada kelas X-5 pada saat mengikuti kegiatan proses belajar mengajar mata pelajaran Sejarah dengan jumlah siswa 33 anak, mayoritas mereka lulusan dari SMP/ SLTP untuk itu dengan menggunakan media grafis dalam pembelajaran Sejarah untuk mempermudah pemahaman siswa.

a. Perencanaan

1) Diskusi dengan Guru Pamong tentang kelas yang akan dipilih. 
2) Diskusi dengan guru mata pelajaran, Dosen pembimbing lapangan tentang penggunaan media grafis dalam proses belajar mengajar.

3) Guru mata pelajaran membantu peneliti sebagai pengamat dalam kegiatan pembelajaran, memantau peneliti dalam melakukan kegiatan belajar mengajar.

4) Membuat perencanaan pembelajaran.

5) Menyusun materi yang akan disampaikan.

6) Membuat alat observasi untuk mengetahui keaktifan dan tingkat kreatifitas siswa dalam proses belajar mengajar.

7) Menyiapkan media grafis yang akan digunakan dalam pembelajaran.

8) Menyusun langkah-langkah pembelajaran.

9) Menyusun alat evaluasi.

b. Pelaksanaan

Pelaksanaan dari tindakan yang akan dilakukan dalam setiap kali pertemuan, yakni dalam 4 kali pertemuan adalah sebagai berikut:

1) Pendahuluan

a) Awali dengan mengucapkan salam dan berdo'a.

b) Penjelasan singkat tentang kompetensi dan materi yang akan dimiliki/dikuasai siswa sebagai hasil belajar

2) Kegiatan Inti
a) Guru memberikan ilustrasi seputar materi dengan menggunakan media grafis
b) Guru membagi siswa menjadi 4 kelompok
c) Tiap kelompok diberi topik yang berbeda
d) Tiap kelompok mengutus perwakilan untuk mempresentasikan hasil diskusi kelompok dan mendemonstrasikan.
e) Guru memberikan kesempatan kepada kepada antar kelompok untuk saling menanggapi.
f) Selama kegiatan berlangsung, guru mengamati dan menilai kinerja siswa.

3) Penutup

a) Guru memberikan feed back terhadap kinerja siswa.

b) Guru memberikan kesempatan pada siswa untuk bertanya.

c) Guru memberi tugas pada siswa untuk merangkum bab yang sudah dipelajari.

d) Diakhiri dengan doa dan salam.

\section{Observasi Dan Interpretasi}

Selama kegiatan pembelajaran berlangsung, peneliti melakukan pengambilan data berupa hasil pengamatandan hasil belajar siswa. Hasil pengamatan dicatat pada lembar observasi tentang perilaku siswa, yaitu: 
1. Kegiatan siswa selama kegiatan belajar mengajar berlangsung

2. Nilai hasil tugas diskusi di kelas dan nilai tes ulangan harian.

\section{Analisis dan Refleksi}

Berdasarkan data yang diperoleh dari tindakan yang telah dilakukan, maka data tersebut dianalisis untuk memastikan bahwa dengan menerapkan media grafis dalam pembelajaran Sejarah dapat mempermudah peserta didik.

Peneliti menggunakan tehnik reduksi data, paparan data, dan kesimpulan. Reduksi data merupakan proses pemilahan data yang relevan dan penting. Langkah yang digunakan yaitu dengan menyederhanakan dengan membuat fokus, klasifikasi, abstraksi data kasar menjadi data yang bermakna untuk dianalisis. Data yang telah direduksi selanjutnya disajikan dalam bentuk paparan data yang memungkinkan untuk ditarik kesimpulan. Kesimpulan merupakan intisari dari analisis yang memberikan dampak dari penelitian tindakan kelas. Data hasil pengamatan dan hasil belajar siswa, setelah dianalisis dapat digunakan untuk menyusun refleksi. Refleksi merupakan bagian integrasi dan interpretasi terhadap semua informasi yang diperoleh.

\section{Siklus Penelitian}

Dalam penelitian tindakan kelas ini, kami bagi menjadi dua siklus. Tiap siklus terdiri empat kali pertemuan. Hal ini berdasarkan 2 pokok bahasan, yakni Proses Terbentuknya Bumi Dan Awal Kehidupan Manusia (4 X 45 menit dengan 4 kali pertemuan), Peradapan Awal Masyarakat Indonesia (4 X 45 menit dengan 4 kali pertemuan).

\section{Instrumen Penelitian}

Dalam penelitian ini peneliti di lapangan menjadi syarat utama, peneliti mengumpulkan data dalam latar alamiah, di mana peneliti bertindak sebagai instrumen kunci. Selain itu peneliti juga berperan sebagai perencana dan pelaksana tindakan kelas yang terlibat langsung, pengumpul dan penganalisis data dan akhirnya menjadi pelapor hasil penelitian. Instrumen pendukung adalah lembar pedoman observasi perilaku siswa di dalam kelas selama proses belajar mengajar dan test ulangan harian.

\section{Pengumpulan Data}

Data yang akurat akan bisa diperoleh ketika proses pengumpulan data tersebut dipersiapkan dengan matang. Dalam penelitian ini akan digunakan beberapa cara untuk mengumpulkan data selama proses penelitian yaitu:

1. Pengamatan Partisipatif. Cara ini digunakan agar data yang diinginkan bisa diperoleh, sesuai dengan apa yang dimaksudkan oleh peneliti. Penelitian Partisipatif maksudnya adalah peneliti terlibat secara langsung dan bersifat aktif dalam turut 
mengumpulkan data yang diinginkan dan juga peneliti kadang-kadang mengarahkan pada data yang ingin diperoleh oleh penelti.

2. Observasi Aktifitas Kelas. Observasi aktifitas kelas dilaksanaka oleh penliti ketika peneliti selama proses belajar mengajar dikelas dengan menggunakan media grafis sehingga peneliti akan memperoleh gambaran suasana kelas dalam penggunaan media grafis dalam sejarah untuk mempermudah pemahaman siswa.

3. Pengukuran Hasil Belajar. Data yang telah diperoleh dilapangan akan diukur untuk peneliti dengan menggunakan pedoman lembar obserfasi perilaku siswa dan presentase hasil nilai ulangan harian kelas.

Untuk mempermudah peneliti dalam mengumpulkan data dan data yang diperoleh tidak hilang maka peneliti melakukan perekaman dengan cara membuat catatan dari hasil yang telah diperoleh selama proses penelitian. Teknik perekaman yang dilakukan adalah dengan membuat catatan-catatan pada pedoman obserfasi berdasarkan perkembangan siswa setiap siklus, yakni siklus I, siklus II dan siklus III.

\section{Indikator Kinerja}

Penelitian yang dilaksanakan selama 6 kali pertemuan dengan observasi kelas, yakni mengikuti mata pelajaran bersama guru pamong pada pertemuan ke-1 dan tes ulangan harian pada pertemuan ke-5 ini sudah cukup menilai penggunaan media grafis dalam pembelajaran sejarah untuk mempermudah pemahaman siswa. Hal ini dapat kita lihat dari nilai tes ulangan harian dan pedoman obserfasi perilaku siswa dalam mengikuti kegiatan belajar mengajar.

\section{Hasil dan Pembahasan}

Uraian berikut adalah salah satu uapaya untuk mendeskripsikan hasil penelitian tindakan kelas yang telah dilaksanakan. Dengan demikian kita akan mengetahui bahwa penggunaan media grafis dalam pembelajaran sejarah dapat mempermudah siswa kelas X-5 di SMA Negeri I Batu.

Penelitian ini dilaksanakan mulai tanggal 2 februari 2009 sampai dengan tanggal 21 Maret 2009 selama 4 kali pertemuan, tiap hari kamis jam ke-1 dan tanggal, 12 Maret 2009 (Ulangan Harian). Dengan demikian, prakter atau proses kegiatan belajar dan mengajar yang dilakukan peneliti hanya berlangsung 4 kali pertemuan dengan 2 pokok bahasan yaitu proses terbentuknya bumi dan awal kehidupan manusia (4 X 45 menit dengan 4 kali pertemuan), peradapan awal masyarakat Indonesia (4 X 45 menit dengan 4 kali pertemuan).

\section{Siklus I}

a. Rencana tindakan siklus I 
Pada perencanaan tindakan I, peneliti menerapkan penggunaan media grafis dalam proses belajar mengajar dengan tujuan untuk mempermudah pemahaman siswa terhadap materi sejarah di kelas X-5 yang siswanya memiliki kemampuan yang hiterogen dengan latar belakang akademik yang berbeda.

Siklus ini terdiri dari satu pokok bahasan, yaitu bab proses terbentuknya bumi dan awal kehidupan manusia (4 X 45 menit dengan 4 kali pertemuan). Sebelum pembelajaran dilaksanakan penelitian ini dimulai dari beberapa tahapan persiapan, yaitu:

1) Membuat rencana pembelajaran meliputi perencanaan satuan dan analisis program

2) Membuat atau menyiapkan media grafis, gambar tentang bumi dan peninggalan zaman prasejarah.

3) Membagi materi terbentuknya bumi dan awal kehidupan manusia. Mempersiapkan grafis atau peta konsep untuk melaksanakan praktek membaca dan mengidentifikasi.

4) Membagi kelas menjadi beberapa kelompok diskusi dan tanya jawab.

5) Membuat alat atau pedoman observasi untuk mengetahui, kinerja siswa, kreatifitas siswa dalam proses belajar mengajar sebagai wujud dari pemahaman siswa terhadap materi yang telah dijelaskan dengan menggunakan media grafis.

b. Pelaksanaan

Pelaksanaan siklus ini terdiri dari satu pokok bahasan, yaitu menganalisis peradapan Indonesia dan Dunia (4X45 menit dengan 4 kali pertemuan), dimana:

\section{Pertemuan I}

1) Pendahuluan

a) Awali dengan mengucapkan salam dan berdo'a.

b) Membahas sedikit tentang sejarah. Pilih materi yang berkaitan dengan topik bahasan.

c) Perkenalan antara peneliti dengan siswa sebagai objek penelitian

d) Penjelasan singkat tentang kompetensi dan materi yang akan dimiliki/dikuasai Siswa sebagai hasil belajar

2) Kegiatan Inti

a) Guru memberikan ilustrasi seputar materi dengan menggunakan media grafis

b) Guru membagi siswa menjadi 4 kelompok

c) Tiap kelompok diberi topik yang berbeda tentang proses terbentuknya bumi dan awal kehidupan manusia. Tiap kelompok mengutus perwakilan untuk mempresentasikan hasil diskusi kelompok dan mendemonstrasikan. 
d) Guru memberikan kesempatan kepada antar kelompok untuk saling menanggapi.

e) Selama kegiatan berlangsung, guru mengamati dan menilai kinerja siswa.

3) Penutup

a) Guru memberikan feed back terhadap kinerja siswa

b) Guru memberikan kesempatan pada siswa untuk bertanya

c) Guru memberi tugas pada siswa untuk merangkum bab yang sudah dipelajari

d) Diakhiri dengan doa dan salam

\section{Pertemuan II :}

1) Pendahuluan

a) Awali dengan mengucapkan salam dan berdo'a.

b) Menyinggung dan memberi pertanyaan sedikit tentang materi kemarin.

c) Penjelasan singkat tentang kompetensi dan materi yang akan dimiliki/dikuasai siswa sebagai hasil belajar

2) Kegiatan Inti

a) Melanjutkan materi yakni menyuruh kelompok yang belum untuk mengutus perwakilan untuk mempresentasikan hasil diskusi kelompok dan mendemonstrasikan.

b) Guru memberikan kesempatan kepada antar kelompok untuk saling menanggapi.

c) Selama kegiatan berlangsung, guru mengamati dan menilai kinerja siswa.

3) Penutup

a) Guru memberikan feed back terhadap kinerja siswa

b) Guru memberikan kesempatan pada siswa untuk bertanya

c) Guru memberi tugas pada siswa untuk merangkum bab yang sudah dipelajari

d) Diakhiri dengan doa dan salam

c. Observasi siklus I

Selama kegiatan pembelajaran, peneliti bertindak sebagai guru sekaligus sebagai observer yang mencatat lembar pengamatan pada pedoman observasi (lampiran 1).Hasil pengamatan pada siklus I, kegiatan siswa cukup baik dengan antusias mengikuti kegiatan belajar mengajar Memasuki kegiatan inti, guru menjelaskan dengan menggunakan media garfis, yaitu gambar zaman prasejarah.Karena mudah memahami keterangan guru, sehingga ketika kegiatan diskusi berlangsung dan tiap kelompok secara bergantian maju untuk mempresentasikan hasil diskusi kelompok dan mendemontrasikan . Setelah siswa 
menerima materi pelajaran dan melakukan diskusi, guru melakukan feed back terhadap hasil diskusi dan memberikan rugas untuk merangkum hasil diskusi.

d. Refleksi siklus I

Penggunaan media grafis dengan menggunakan gambar tentang zaman prasejarah pada siklus I berjalan dengan cukup baik. Hal ini terlihat pada antusias siswa dalam mengikuti pelajaran dan kreatifitas siswa dalam kegiatan diskusi serta pelaksanaan demontasi dari tiap-tiap poses munculnya kehidupan awal manusia. Hal ini tidak terlepas dari minimnya tingkat pengetahuan mereka tengtang sejarah. Menyikapi kenyataan di atas maka diambil langkah-langkah:

1) Memacu siswa untuk berani engungkapkan gagasannya.

2) Memacu siswa untuk lebih banyak membaca buku-buku sejarah, dan memberi mereka untuk berkonsultais pada guru mata pelajaran di luar jam pelajaran.

\section{Siklus II}

a. Rencana siklus II

Pada perencanaan tindakan II, peneliti menerapkan penggunaan media grafis dalam pembelajaran sejarah dengan tujuan untuk mempermudah pemahaman siswa kelas 5.

Siklus II ini terdiri dari satu pokok bahasan, yaitu bab kehidupan awal mayarakat indonesia (4X45 menit dengan 4 kali pertemuan). Sebelum pembelajaran dilaksanakan penelitian ini dimulai dari beberapa tahapan persiapan, yaitu:

1) Membuat rencana pembelajaran meliputi perencanaan satuan dan analisis program

2) Membuat atau menyiapkan media grafis yang berkaitan dengan materi zaman prasejarah

3) Membagi kelas menjadi beberapa kelompok diskusi dan tanya jawab

4) Membuat alat observasi untuk mengetahui, kretifitas kinerja siswa, antusias siswa dalam proses belajar mengajar sebagai akibat dari pemahaman siswa terhadap penyajian materi dengan menggunakan media grafis

b. Pelaksanaan

Pelaksanaan siklus II ini juga terdiri dari satu pokok bahsan yaitu (4X45 menit dengan 4 kali pertemuan).

Pertemuan I :

1) Pendahuluan

a) Awali dengan mengucapkan salam dan berdo'a.

b) Menyinggung dan memberi pertanyaan sedikit tentang materi kemarin.

c) Penjelasan singkat tentang kompetensi dan materi yang akan dimiliki/dikuasai Siswa sebagai hasil belajar 
2) Kegiatan Inti

a) Guru memberikan ilustrasi seputar materi dengan mengunakan media grafis, yakni hasil budaya dan alat-alat untuk berburu dan mengumpulkan makanan

b) Guru membagi siswa menjadi 4 kelompok

c) Tiap kelompok diberi permasalahan yang berbeda tentang materi yang dibahas

d) Tiap kelompok mengutus perwakilan untuk mempresentasikan hasil diskusi kelompoknya

e) Guru memberikan kesempatan kepada antar kelompok untuk saling menanggapi.

f) Selama kegiatan berlangsung, guru mengamati dan menilai kinerja siswa.

3) Penutup

a) Guru memberikan feed back terhadap kinerja siswa

b) Guru memberikan kesempatan pada siswa untuk bertanya

c) Guru memberi tugas pada siswa untuk merangkum bab yang sudah dipelajari

d) Diakhiri dengan doa dan salam

Pertemuan II :

1) Pendahuluan

a) Awali dengan mengucapkan salam dan berdo'a.

b) mengulas dan memberi pertanyaan sedikit tentang materi kemarin.

c) Penjelasan singkat tentang kompetensi dan materi yang akan dimiliki/dikuasai siswa sebagai hasil belajar

2) Kegiatan Inti

a) Melanjutkan materperadapan awal masyarakat Indonesia yakni menyuruh kelompok yang belum untuk mengutus perwakilan untuk mempresentasikan hasil diskusi kelompok

b) Guru memberikan kesempatan kepada kepada kelompok lain untuk saling menanggapi.

c) Selama kegiatan berlangsung, guru mengamati dan menilai kinerja siswa.

3) Penutup

a) Guru memberikan feed back terhadap kinerja siswa

b) Guru memberikan kesempatan pada siswa untuk bertanya

c) Guru memberi tugas pada Siswa untuk merangkum bab yang sudah dipelajari

d) Diakhiri dengan doa dan salam

c. Observasi siklus II 
Selama kegiatan pembelajaran, peneliti bertindak sebagai guru sekaligus sebagai observer yang mencatat lembar pengamatan pada pedoman observasi (lampiran 2).Hasil pengamatan siklus II kegiatan siswa sudah baik dengan antusias dalam mengikuti KBM. Memasuki kegiatan inti, guru menjelaskan dengan menggunakan media grafish, yaitu tulisan di kertas manilla tentang pengaru peradapan dunia terhadap peradapan Indonesia. Serta gambar hasil budaya dan alat-alat yang dihasilkan terkait dengan materi agar mempermudah siawa dalam memahami keterangan guru, sehingga ketika kegiatan diskusi berlangsung dan tiap kelompok secara bergantian maju untuk mempresentasikan hasil diskusi kelompok. Setelah siswa menerima materi pelajaran dan melakukan diskusi, guru melakukan feed back terhadap hasil diskusi dan memberikan tugas untuk merangkum hasil diskusi kelas.

d. Refleksi siklus II

Penggunaan media grafis dengan menggunakan tulisan dikertas manilla dan gambar hasil budaya dan alat-alat yang dihasilkannya pada siklus II berjalan dengan baik. Hal ini terlihat pada antusias siswa dalam mengikuti pelajaran dan kretifitas siswa dalam kegiatan diskusi memahami materi. Oleh karena itu perlu diambil langkah-langkah:

1) Kualitas belajar siswa perlu dipacu lagi khususnya menyangkut kemampuan siswa dalam mengemukakan pendapat dan melatih siswa untuk dapat menarik kesimpulan dengan kalimat sendiri.

Menjaga agar kualitas aspek belajar yang sudah berkembang dengan baik tetap terpelihara dan memotifasinya agar lebih meningkatkan disiplin belajar.

\section{Simpulan}

Dari paparan data di atas dapat diketahui bahwa penggunaan media grafis dalam pembelajaran Sejarah dapat mempermudah pemahaman siswa kelas 5 MI Darul Ulum Bojonegoro. Selanjutnya dapat diambil kesimpulan sebagai berikut :

1. Penggunaan media grafis dapat mempermudah siswa dalam memahami peta konsep dalam pelajaran sejarah

2. Penggunaan media grafis mempermudah guru dalam menjelaskan mata pelajaran sejarah dengan efektif dan efisien, dan mempermudah siswa dalam memahami materi Sejarah. Hal ini tercermin dari beberapa hal, yaitu:

a. Antusias, kecerian dan kretafitas dalam bentuk keaktifan siswa dalam proses belajar mengajar.

b. Kemampuan siswa dalam mempresentasikan hasil diskusi kelompok dan tugas merangkum hasil diskusi dengan mengunakan bahasa sistematis

c. Hasil tes ulangan harian yang mencrminkan kelulusan $100 \%$ 


\section{Daftar Rujukan}

Anselm, D. (1997). Dasar-dasar Penelitian Kualitatif: Prosedur, Tehnik danTeori Grounded. PT. Bina Ilmu.

Arief S. (n.d.). Media Pengajaran (Pengertian, Pengembangan dan Pemanfaatan). Jakarta: PT Raja Grafindo Persada.

Arsad, A. (1997). Media Pengajaran (P. R. G. Persada, ed.). Jakarta.

Arsyad, A. (2002). Media Pembelajaran. Jakarta: PT. Raja Grafindo Persada.

Darajat, Z. (1987). Dasar-Dasar Agama Islam: Buku Teks Pendidikan Agama Islam Pada Perguruan Tinggi Umum. Jakarta: Bulan Bintang.

Hamalik, O. (2001). Proses Belajar Mengajar. Bandung: Bumi Aksara.

Muhaimin. (2001). Paradigma Pendidikan Islam. Bandung: PT Remaja Rosda Karya.

Muhaimin, D. (2002). Paradigma Pendidikaan Islam. Surabaya: PT Remaja Rosda Karya.

Saputro, S. (1993). Dasar-dasar Metodologi Pengajaran Umum. Malang: IKIP.

Soedarsono, F. . (n.d.). AplikasiPenelitian Tindakan Kelas. Departemen Pendidikan Nasional.

Soetomo. (1993). Dasar-dasar Interaksi Belajar Mengajar. Surabaya: Usaha Nasional.

Sudjana, N. (1989). Media Pengajaran. Bandung: Sinar Baru. 